\title{
PENGARUH SOCIAL MEDIA MARKETING TERHADAP KEPUTUSAN PEMBELIAN KONSUMEN PADA DESTINASI WISATA KULINER DI KOTA DENPASAR
}

\author{
Nararya Narottama \\ Fakultas Pariwisata, Universitas Udayana \\ Email: nararya.narottama@unud.ac.id \\ Natasha Erinda Putri Moniaga \\ Fakultas Pariwisata, Universitas Udayana \\ Email: erindaputri19@unud.ac.id
}

\begin{abstract}
Pesatnya pertumbuhan destinasi wisata kuliner di kota Denpasar, memberikan banyak alternatif pilihan bagi para calon konsumen. Di sisi lain, hal ini membuat tingkat persaingan usaha kuliner menjadi semakin ketat dan berbagai upaya dilakukan oleh para pengusaha kuliner untuk merebut hati konsumen mereka. Salah satu strategi yang dilakukan adalah pemasaran melalui media sosial atau social media marketing (SMM). Penelitian ini bertujuan untuk menganalisa pengaruh SMM terhadap keputusan pembelian konsumen pada destinasi wisata kuliner Kota Denpasar, menggunakan jenis penelitian explanatory yang berbasis pada pendekatan metode campuran (mix method) kuantitatif dan kualitatif, menggunakan lima variabel independen, yakni Content Creation (X1), Content Sharing (X2), Connecting (X3), Community Building (X4), dan sebuah variabel dependen, yakni Keputusan Pembelian (Y). Penelitian ini menggunakan teknik mix method, metode pengumpulan data melalui survei dan penyebaran kuisioner online pada destinasi wisata kuliner populer di kota Denpasar sebagai lokus utama, mewakili populasi di empat kecamatan, yakni Denpasar Utara, Denpasar Timur, Denpasar Selatan dan Denpasar Barat pada periode satu tahun penelitian, serta dilengkapi dengan observasi dan wawancara mendalam kepada informan kunci. Teknik analisis data menggunakan analisis regresi logistik, kemudian analisis deskriptif digunakan untuk menjelaskan makna-makna yang terkandung di dalamnya. Penelitian ini bermanfaat untuk membantu para pengusaha wisata kuliner, pemangku kepentingan, praktisi dan akademisi pariwisata dalam mengungkap pengaruh SMM terhadap keputusan pembelian konsumen, dan bermuara pada penyusunan strategi pemasaran yang tepat untuk memenangkan persaingan.
\end{abstract}

Keywords: wisata kuliner, social media marketing, keputusan pembelian. 


\section{Pendahuluan}

Perkembangan teknologi telah memberikan banyak manfaat bagi manusia. Pada era digital ini, hampir seluruh aspek kehidupan manusia tergantung pada internet. Keberadaan internet dan piranti pendukungnya berhasil mengubah cara manusia untuk berkomunikasi dan bersosialisasi. Melalui media sosial, manusia saling terhubung antara satu dan lainnya, baik dalam lingkup lokal hingga internasional karena jarak dan waktu tidak lagi menjadi kendala.

Selama beberapa dekade terakhir, penggunaan dan popularitas sosial media terus meningkat. Ashley dan Tuten (2015, dalam Mbwana, 2018) meramalkan bahwa fenomena ini akan terus berlanjut di masa depan. Berdasarkan data dari datareportal.com (https://datareportal.com/reports/digital-2020-july-global-statshot, diakses pada tanggal 25 November 2020), pada bulan Juli 2020 sebanyak 3, 96 milyar orang (lebih dari separuh penduduk dunia) menggunakan media sosial, dengan ratarata pertambahan 12 pengguna baru setiap detiknya. Per Juli 2021, angka tersebut meningkat mencapai 4, 48 milyar orang di seluruh dunia atau mencakup 56,8\% dari seluruh populasi dunia, dimana 99\% mengaksesnya melalui smartphone (State of Digital-https://datareportal.com/reports/digital-2021-global-overview-report).

Fenomena ini seiring pembatasan mobilitas sosial di berbagai negara karena pandemic Covid-19 belakangan ini. Platform media sosial yang paling banyak digunakan antara lain: Facebook, Youtube, Whats App, FB Messenger, We Chat, Instagram, Tiktok, QQ, Weibo, Qzone, Reddit, Douyin, Kuaishou, Snapchat, Pin Interest dan Twitter. Dengan cakupan yang sangat luas dan biaya (cost) yang rendah, media sosial merupakan alat yang tepat serta sangat kuat (powerful) untuk menghubungkan antara konsumen dan bisnis dalam skala regional, nasional dan bahkan internasional. 
Menurut Kotler \& Keller (2012:568) media sosial adalah merupakan sebuah sarana bagi konsumen untuk berbagi informasi baik itu dalam bentuk teks, gambar, audio dan video dengan satu sama lain. Sedangkan Caleb T. Carr dan Rebecca A. Hayes (2015), menyatakan bahwa media sosial adalah media berbasis internet yang memungkinkan pengguna berkesempatan untuk berinteraksi dan mempresentasikan diri, baik secara seketika ataupun tertunda, dengan khalayak luas maupun tidak, yang mendorong nilai dari user-generated content dan persepsi interaksi dengan orang lain. Dari dua penjelasan di atas, secara garis besar, dapat disimpulkan bahwa media sosial adalah media berbasis internet yang memungkinkan pengguna berkesempatan untuk berinteraksi lewat berbagi teks, gambar, suara, dan video mengenai berbagai macam informasi, termasuk dalam konteks pemasaran atau marketing.

Sejak tahun 2010, Pemerintah Kota Denpasar berupaya keras mengembangkan wisata kuliner dengan melakukan berbagai kampanye dan promosi (Kompas.com, 2020). Kota Denpasar memiliki berbagai destinasi wisata kuliner yang menyediakan berbagai makanan khas Bali, beragam jenis makanan Nusantara hingga kuliner internasional. Berdasarkan data dari Dinas Pariwisata Kota Denpasar, pada tahun 2019 terdapat 893 ragam usaha jasa penyedia makanan dan minuman, dengan sebaran di Denpasar Selatan sebanyak 338 usaha, Denpasar Timur sebanyak 338 usaha, Denpasar Barat sebanyak 230 usaha, dan Denpasar Utara sebanyak 144 usaha (Dinas Pariwisata Kota Denpasar, 2019). Data tersebut belum mencakup usaha yang tidak terdaftar secara resmi, sehingga penulis meyakini bahwa jumlah usaha penyedia makanan dan minuman di Kota Denpasar sebenarnya jauh lebih tinggi.

Mengingat perkembangan wisata kuliner di Kota Denpasar yang berkembang pesat, maka persaingan di dalamnya pun semakin ketat. Pesatnya pertumbuhan destinasi wisata kuliner di kota Denpasar, memberikan banyak alternatif pilihan bagi para calon konsumen. Di sisi lain, hal ini membuat tingkat persaingan usaha kuliner menjadi semakin ketat dan berbagai upaya dilakukan oleh para pengusaha kuliner untuk merebut hati konsumen mereka. Salah satu strategi yang populer dilakukan 
oleh para pengusaha kuliner di Kota Denpasar adalah pemasaran melalui media sosial atau social media marketing.

Social media marketing adalah sebuah proses yang mendorong individu untuk melakukan promosi melalui situs web, produk, atau layanan mereka melalui saluran sosial online dan untuk berkomunikasi dengan memanfaatkan komunitas yang jauh lebih besar yang memiliki kemungkinan lebih besar untuk melakukan pemasaran daripada melalui saluran periklanan tradisional (Weinberg, 2009:3-4). Menurut Tuten, (2008:19), social media marketing merupakan bentuk periklanan secara online yang menggunakan konteks kultural dari komunitas sosial meliputi jejaring sosial, dunia virtual, situs berita sosial, dan situs berbagi pendapat sosial untuk menemui tujuantujuan komunikasi. Dalam konteksnya sebagai sebuah strategi pemasaran, social media marketing bertujuan membangun dan memelihara keterlibatan para pengikut (followers) maupun anggota komunitas online yang memiliki minat dan ketertarikan yang sama Social media marketing yang dilakukan oleh suatu bisnis dapat mempengaruhi pemikiran seseorang yang akan berdampak pada pemikiran orang lainnya secara lebih luas sebelum melakukan keputusan pembelian (Gunelius, 2011:144-145). Jika diaplikasikan secara tepat, maka social media marketing dapat meningkatkan kesadaran atau produk/jasa, meningkatkan minat target pasar untuk mengambil keputusan pembelian, melakukan konsumsi, sekaligus memperkuat loyalitas konsumen. Sumarwan (2014:377 dikutip dalam Mileva dan Fauzi, 2018) menyatakan bahwa keputusan pembelian merupakan keputusan konsumen yang meliputi keputusan konsumen mengenai apa yang akan dibeli, apakah akan melakukan pembelian atau tidak, kapan membeli, dimana membeli, dan bagaimana cara membayarnya.

Perkembangan teknologi (terutama internet) membantu konsumen untuk memperoleh akses informasi dengan cepat dan mudah. Hal ini juga berdampak pada perubahan gaya hidup konvensional menjadi serba online. Fenomena ini merupakan peluang sekaligus tantangan bagi para pengusaha kuliner di Kota Denpasar. Untuk 
meraih hati konsumen dan bisa bersaing di era saat ini, maka pengusaha kuliner harus mampu merumuskan dan mengimplementasikan strategi pemasaran media sosial yang tepat. Namun sebelum itu, perlu dianalisa terlebih dahulu bagaimana pengaruh social media marketing terhadap keputusan pembelian kondsumen. Berdasarkan pemaparan di atas, rumusan masalah yang akan dibahas dalam penelitian ini adalah: Bagaimanakah pengaruh Social Media Marketing terhadap keputusan pembelian konsumen di destinasi wisata kuliner di Kota Denpasar? Dengan demikian, penelitian ini secara khusus bertujuan membantu para pengusaha, stakeholder, praktisi dan akademisi pariwisata dalam mengungkap pengaruh social media marketing terhadap keputusan pembelian konsumen di destinasi wisata kuliner di Kota Denpasar.

\section{Tinjauan Pustaka}

Perkembangan teknologi (terutama internet) membantu konsumen untuk memperoleh akses informasi dengan cepat dan mudah. Hal ini juga berdampak pada perubahan gaya hidup konvensional menjadi serba online. Fenomena ini merupakan peluang sekaligus tantangan bagi para pengusaha kuliner di Kota Denpasar. Untuk meraih hati konsumen dan bisa bersaing di era saat ini, maka pengusaha kuliner harus mampu merumuskan dan mengimplementasikan strategi pemasaran media sosial yang tepat. Namun sebelum itu, perlu dianalisa terlebih dahulu bagaimana pengaruh social media marketing terhadap keputusan pembelian kondsumen. Berdasarkan pemaparan di atas, rumusan masalah yang akan dibahas dalam penelitian ini adalah: Bagaimanakah pengaruh Social Media Marketing terhadap keputusan pembelian konsumen di destinasi wisata kuliner di Kota Denpasar? Dengan demikian, penelitian ini secara khusus bertujuan membantu para pengusaha, stakeholder, praktisi dan akademisi pariwisata dalam mengungkap pengaruh social media marketing terhadap keputusan pembelian konsumen di destinasi wisata kuliner di Kota Denpasar.

Saat ini, dunia maya atau dunia virtual telah menjadi media penting untuk kolaborasi formal (maupun non formal) antara konsumen dan organisasi, dimana 
lingkungan bisnis virtual merupakan penentu penting bagi daya saing usaha (Cohen, 2008). Media sosial seperti Instagram, Facebook, Twitter, YouTube dan lain-lain adalah merupakan alat dinamis yang mampu memfasilitasi hubungan online, sekaligus bentuk pemasaran yang relatif murah dan memungkinkan organisasi untuk terlibat dalam kontak langsung dengan pengguna akhir atau konsumen mereka (Kaplan dan Haenlein, 2010; Golden, 2011). Pertumbuhan media sosial meningkatkan kesadaran situasional (baik bagi pemasar maupun konsumen - dalam konteks lingkungan bisnis yang berubah) dengan demikian pemasaran melalui media sosial memainkan peran yang semakin penting dalam dunia pemasaran saat ini (Cuming, 2008; Mayfield, 2011).

Hal ini sesuai dengan penelitian yang dilakukan oleh Fauser dkk (2011) yang menyimpulkan bahwa pemasaran media sosial adalah alat penting untuk memasarkan merek dan produk, yang disebabkan oleh perkembangan pesat di media sosial dan perubahan perilaku konsumen saat ini. Hasil penelitian dari Cuming (2008) mengungkapkan bahwa informasi online memainkan peran yang berpengaruh dalam keputusan pembelian akhir konsumen, sekaligus menyimpulkan bahwa konsumen yang sering mengunjungi platform media sosial lebih mungkin terpengaruh dalam keputusan pembelian akhir mereka.

Moriansyah (2015) menyatakan bahwa media sosial merupakan alat komunikasi pemasaran yang memiliki kemampuan yang besar karena kemampuan komunikasi dengan cakupan yang luas, kemampuan berbagi informasi, dan memecahkan batasan geografis. Pernyataan tersebut selaras dengan penelitian yang dilakukan oleh Umami (2015) yang menyatakan bahwa promosi menggunakan media sosial sangat efektif pada sasaran yang dituju yaitu wisatawan dan calon wisatawan. Selain efektif pada sasaran yang dituju, Umami juga menegaskan bahwa target promosi melalui social media menjadi luas dan sebagian besar pengguna media sosial dapat mengakses atau mendapatkan informasi dengan cepat dan akurat. 
Pada berbagai literature lainnya, penelitian maupun kajian mengenai pemasaran melalui media sosial (social media marketing) maupun perilaku konsumen telah banyak dilakukan baik (Mileva dan Fauzi, 2018; Gunelius, 2011; Sumarwan, 2014; Tuten, 2008; Zimmerman dan Sahlin, 2010). Namun sejauh pengetahuan penulis, belum ada yang secara spesifik membahas mengenai pengaruh social media marketing terhadap keputusan pembelian konsumen pada destinasi wisata kuliner di Kota Denpasar. Meski penelitian ini menggunakan variabel yang sama dengan Mileva dan Fauzi (2018) serta Wilem dkk (2020), namun fokus dan lokus penelitian ini jauh berbeda.

\section{Variabel Operasional dan Hipotesis}

\section{Social Media Marketing}

Merujuk dari asal katanya, social media marketing (pemasaran media sosial) merupakan gabungan dari konsep social media dan merketing. Pada konteks pemasaran, media sosial merupakan sarana (platform) dimana orang-orang bisa membangun jejaring (network), berbagi informasi dan bahkan perasaan (sentiment) ((Kaplan dan Haenlein, 2010). Menurut Gunelius (2011:10; Mileva dan Fauzi, 2018) social media marketing merupakan suatu bentuk pemasaran langsung ataupun tidak langsung yang digunakan untuk membangun kesadaran, pengakuan, daya ingat, dan tindakan untuk merek, bisnis, produk, orang, atau entitas lainnya dan dilakukan dengan menggunakan alat dari web sosial seperti blogging, microblogging, social networking, social bookmarking, dan content sharing.

Gunelius (2011; dikutip oleh Mileva dan Fauzi, 2018) menjabarkan ada empat alat yang bisa digunakan untuk memaksimalkan partisipasi dalam social media marketing (the $4 C^{\prime}$ 's of social media marketing participation), yakni :

1. Content Creation, yakni dengan menciptakan konten-konten unik yang terkait dengan usaha, pastikan konten tersebut mewakili brand, sekaligus bermanfaat dan menarik bagi target pasar atau calon konsumen. 
2. Content Sharing, yakni dengan membagikan konten-konten terkait usaha kepada target pasar atau calon kunsumen, jika memungkinkan konten tersebut bisa dibagikan kembali (republished) oleh para audiens online, dengan demikian bisa menjangkau pasar potensial yang lebih luas

3. Connecting: Memastikan konten tersebut bisa terhubung dengan audiens online dan jejaring sosial lainnya, dengan demikian bisa membangun kredibilitas brand sekaligus membangun loyalitas

4. Community Building, yakni dengan membangun komunitas sosial yang memungkinkan seseorang bertemu dengan lebih banyak orang yang memiliki minat yang sama, membangun komunitas sosial dapat membantu memperluas jaringan sebuah bisnis dan memperluas jangkauan audiens secara online.

Menurut Gunelius (2011) inti dari berbagai web sosial maupun social media marketing adalah pada istilah «sosial», terutama dalam konteks komunikasi dan jejaring di antara penggunanya. Dengan demikian social media marketing menawarkan peluang terbesar bagi para pengusaha untuk membangun brand dan bisnis mereka pada pangsa pasar yang lebih luas. Pada penelitian ini, keempat variabel di atas digunakan sebagai variabel independen atau variabel bebas, yakni variabel yang mempengaruhi atau menjadi penyebab timbulnya variabel lain yang disebut variabel dependen atau variabel terikat.

\section{Keputusan Pembelian}

Kotler dan Armstrong (2011:154) menyatakan bahwa keputusan pembelian (purchase decision) merupakan salah satu bagian dari seluruh proses pembelian, yakni keputusan yang diambil oleh konsumen mengenai brand (poduk dan jasa) mana yang dibeli atau dikonsumsi. Keputusan pembelian dipengaruhi beberapa faktor psikologis, yakni motivasi, pesepsi, pembelajaran, kepercayaan dan perilaku. (Kotler dan Armstrong, 2011:159). Pendapat tersebut senada dengan Sumarwan (2014:377; 
dalam Mileva dan Fauzi, 2018) yang menyatakan bahwa keputusan pembelian merupakan keputusan konsumen yang akan terjadi jika keinginan konsumen untuk membeli suatu barang sudah bulat yang meliputi mengenai barang apa yang akan dibeli, apakah membeli atau tidak, kapan membeli, dimana membeli, bagaimana cara membayarnya, dan sebagainya. Dengan demikian keputusan pembelian akan terjadi jika konsumen sudah menemukan suatu barang sesuai dengan kriteria yang telah ditetapkan sejak awal yang dipengaruhi oleh beberapa faktor (budaya, sosial, personal dan psikologis) yang dapat menunjang terjadinya pembelian.

Menurut Kotler dan Armstrong (2011:152), proses pengambilan keputusan pembelian (The Buyer Decision Process) terdisi dari lima tahapan, yakni:

1. Pengenalan kebutuhan (needs recognition), dimana calon konsumen memiliki kesadaran dan mengenali permasalahan atau kebutuhan mereka. Kesadaran ini dipicu oleh rangsangan dari dalam (internal stimuli) maupun rangsangan dari luar (external stimuli).

2. Pencarian informasi (information search), calon konsumen yang tertarik mungkin akan mencari informasi lebih lanjut mengenai produk/jasa yang ditawarkan, baik melalui sumber pribadi (keluarga, teman dll), sumber komersial (iklan, pajangan, website dll), sumber publik (media massa, internet) dan sumber berbasis pengalaman (memegang, mengamati, menggunakan produk)

3. Evaluasi alternatif (evaluation of alternatives), dimana calon konsumen mencoba membandingkan berbagai alternatif brand (produk/jasa) yang tersedia di pasar secara kalkulatif dan logis. Evaluasi ini bisa dengan membaca review/testimoni online, mendapat nasihat dari teman/keluarga dll

4. Keputusan pembelian (purchase decision), terjadi dimana konsumen memilih brand (produk/jasa) yang disukai dan dianggap terbaik, kemudian membelinya. 
5. Perilaku pasca pembelian (post-purchase behavior), merupakan tahapan dimana konsumen mengambil tindakan lebih lanjut terkait kepuasan maupun ketidakpuasan mereka terhadap produk/jasa yang mereka beli/konsumsi.

Pada penelitian ini, keputusan pembelian menjadi variabel dependen atau terikat, yang dipengaruhi atau sebagai akibat dari adanya variabel independen atau bebas.

\section{Hipotesis}

Berdasarkan pemaparan di atas, maka dapat ditentukan hipotesis sebagai berikut:

1. H1: Social Media Marketing yang terdiri dari Content Creation (X1), Content Sharing (X2), Connecting (X3), Community Building (X4) berpengaruh signifikan secara simultan terhadap variabel Keputusan Pembelian (Y).

2. H2: Variabel Content Creation (X1) berpengaruh signifikan secara parsial terhadap variabel Keputusan Pembelian (Y).

3. H3: Variabel Content Sharing (X2) berpengaruh signifikan secara parsial terhadap variabel Keputusan Pembelian (Y).

4. H4: Variabel Connecting (X3) berpengaruh signifikan secara parsial terhadap Keputusan Pembelian (Y).

5. H5: Variabel Community Building (X4) berpengaruh signifikan secara parsial terhadap Keputusan Pembelian (Y). 


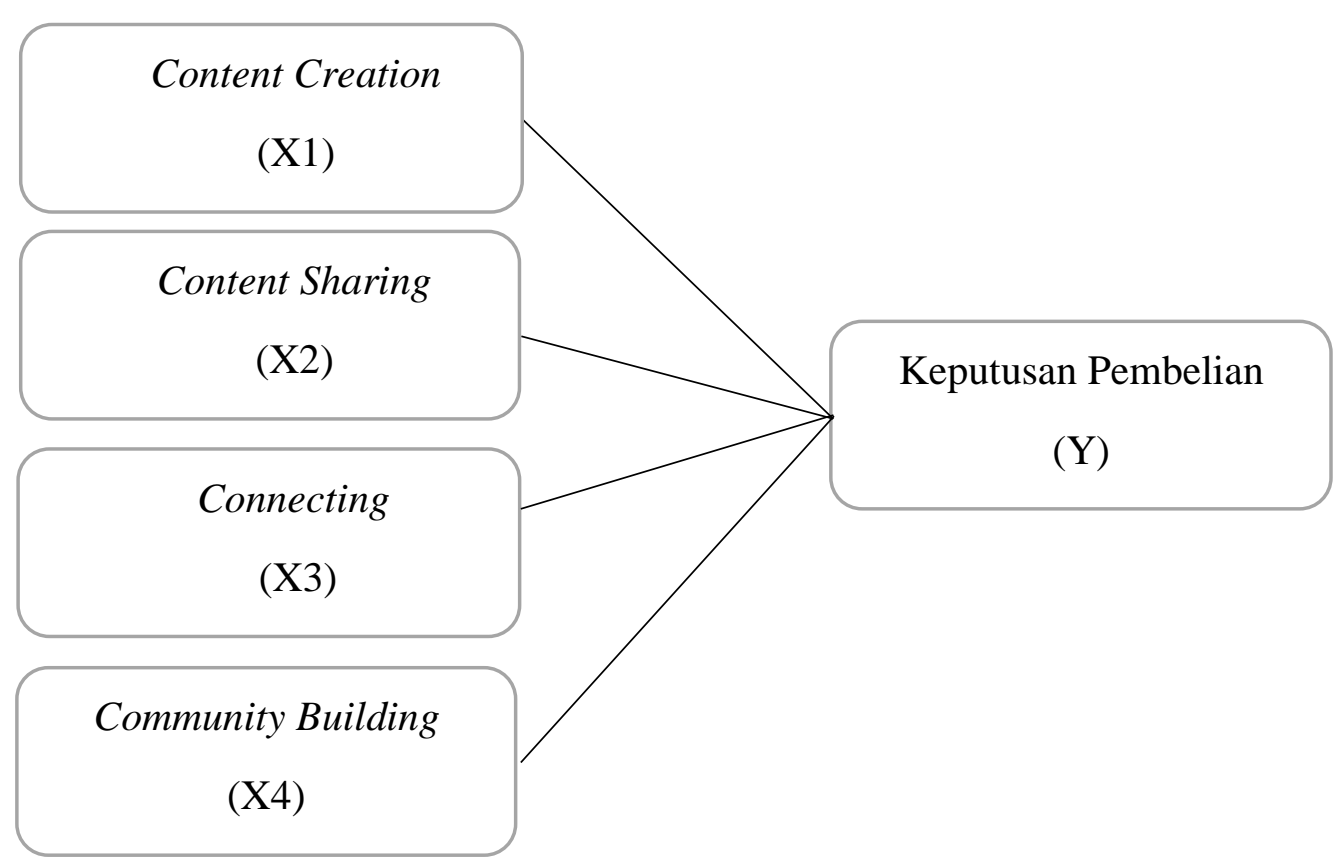

Gambar 1. Model Hipotesis Penelitian

\section{Metode dan Prosedur}

Untuk menganalisis pengaruh social media marketing terhadap keputusan pembelian konsumen di destinasi wisata kuliner Kota Denpasar, penelitian ini menggunakan pendekatan mix method (kuantitatif dan kualitatif), yakni desain penelitian kausal, dengan metode pengumpulan data berupa survey - penyebaran kuesioner, yang digabungkan dengan observasi, dan wawancara pada periode satu tahun penelitian. Metode mix method dipilih untuk memperoleh penjelasan dan pemahaman riil serta mendalam mengenai hubungan sebab akibat antara berbagai variabel atas suatu fenomena sosial. Sebelum disebarkan, daftar pertanyaan kuisioner melalui proses uji validitas dan reliabilitas untuk mengetahui kualitas dari instrumen penelitian yang digunakan. Populasi penelitian ini adalah para pengunjung destinasi wisata kuliner di Kota Denpasar. Penentuan sampel secara sengaja, yang didasarkan pada kriteria tertentu (purposive sampling), antara lain: menggunakan media sosial dan pernah berkunjung ke destinasi wisata kuliner Kota Denpasar. Penelitian ini berhasil mengumpulkan informasi dari 200 responden, beserta pemilik usaha kuliner 
di Kota Denpasar. Data diolah dengan bantuan SPSS menggunakan model regresi logistik.

\section{Lokus Penelitian}

Lokus penelitian adalah Kota Denpasar, yang terdiri dari 4 kecamatan, yakni Denpasar Utara, Denpasar Timur, Denpasar Selatan dan Denpasar Barat dengan total luas wilayah sebesar 127,78 $\mathrm{km}^{2}$ atau 2,18\% dari luas wilayah Provinsi Bali. Lokasi ini ditentukan secara sengaja dengan beberapa pertimbangan, antara lain: 1). Kota Denpasar saat ini tengah menggalakkan wisata kuliner sebagai bagian dari pengembangan ekonomi kreatif. 2). Kota Denpasar memiliki beragam destinasi wisata kuliner terkenal dengan tingkat persaingan yang tinggi. 3). Sejauh pengetahuan penulis, penelitian yang mengkhusus membahas mengenai pengaruh Social Media Merketing terhadap pengambilan keputusan konsumen di destinasi wisata kuliner Kota Denpasar belum pernah dilakukan.

\section{Uji Validitas}

Uji validitas dilakukan untuk mengetahui sejauh mana ketepatan kuisioner dalam mengukur sesuatu yang akan diteliti. Berdasarkan syarat lolos uji validitas, nilai pearson correlation wajib di atas 0,30 atau nilai sig. 2 tailed nya di bawah 0,05, selain itu dinyatakan tidak lolos uji validitas.

Dari hasil uji validitas terhadap item pertanyaan dalam kuesioner, hampir seluruhnya lolos, kecuali item pernyataan X2.3 yang nilai pearson-nya di bawah 0,3 atau signifikansinya di atas 0,05. Karena X2.3 tidak lolos uji validitas, maka item pernyataan ini dihilangkan dari kuesioner dan telah diuji kembali. 
Pengaruh Social Media Marketing Terhadap Keputusan Pembelian Konsumen...

Tabel 1. Validitas X1 (Content Creation)

\begin{tabular}{|c|c|c|c|c|c|c|c|}
\hline & & X1.1 & $\mathrm{X} 1.2$ & X1.3 & X1.4 & X1.5 & $\begin{array}{l}\text { Content } \\
\text { Creation }\end{array}$ \\
\hline X1.1 & $\begin{array}{l}\text { Pearson Correlation } \\
\text { Sig. (2-tailed) } \\
\text { N }\end{array}$ & 37 & \begin{tabular}{r|}
, $666^{* *}$ \\
, 000 \\
37
\end{tabular} & $\begin{array}{r}, 656^{* *} \\
, 000 \\
37\end{array}$ & $\begin{array}{r}, 624^{* *} \\
, 000 \\
37\end{array}$ & $\begin{array}{r}, 458^{* *} \\
, 004 \\
37\end{array}$ & $\begin{array}{r}, 782^{* *} \\
, 000 \\
37\end{array}$ \\
\hline $\mathrm{X} 1.2$ & $\begin{array}{l}\text { Pearson Correlation } \\
\text { Sig. (2-tailed) } \\
\text { N }\end{array}$ & $\begin{array}{r}, 666^{* *} \\
, 000 \\
37\end{array}$ & 1 & \begin{tabular}{r|}
, $906 * *$ \\
, 000 \\
37
\end{tabular} & $\begin{array}{r}, 689^{* *} \\
, 000 \\
37\end{array}$ & $\begin{array}{r}, 776^{* *} \\
, 000 \\
37\end{array}$ & $\begin{array}{r}, 940^{* * *} \\
, 000 \\
37\end{array}$ \\
\hline $\mathrm{X} 1.3$ & $\begin{array}{l}\text { Pearson Correlation } \\
\text { Sig. (2-tailed) } \\
\mathrm{N}\end{array}$ & $\begin{array}{r}, 656^{* *} \\
, 000 \\
37\end{array}$ & \begin{tabular}{r|}
, $906^{* *}$ \\
, 000 \\
37
\end{tabular} & 37 & $\begin{array}{r}, 675^{* *} \\
, 000 \\
37\end{array}$ & $\begin{array}{r}, 847^{* * *} \\
, 000 \\
37\end{array}$ & $\begin{array}{r}, 953^{* *} \\
, 000 \\
37\end{array}$ \\
\hline X1.4 & $\begin{array}{l}\text { Pearson Correlation } \\
\text { Sig. (2-tailed) } \\
\text { N }\end{array}$ & $\begin{array}{r}, 624^{* *} \\
, 000 \\
37\end{array}$ & \begin{tabular}{r|}
, $689^{* *}$ \\
, 000 \\
37
\end{tabular} & $\begin{array}{r}, 675^{* *} \\
, 000 \\
37\end{array}$ & 37 & $\begin{array}{r}, 516^{* *} \\
, 001 \\
37\end{array}$ & $\begin{array}{r}, 805^{* *} \\
, 000 \\
37\end{array}$ \\
\hline X1.5 & $\begin{array}{l}\text { Pearson Correlation } \\
\text { Sig. (2-tailed) } \\
\text { N }\end{array}$ & $\begin{array}{r}, 458^{* *} \\
, 004 \\
37\end{array}$ & $\begin{array}{r}, 776^{* *} \\
, 000 \\
37\end{array}$ & $\begin{array}{r}, 847^{* * *} \\
, 000 \\
37\end{array}$ & $\begin{array}{r}, 516^{* *} \\
, 001 \\
37\end{array}$ & 1 & $\begin{array}{r}, 835^{* *} \\
, 000 \\
37\end{array}$ \\
\hline $\begin{array}{l}\text { Content } \\
\text { Creation }\end{array}$ & $\begin{array}{l}\text { Pearson Correlation } \\
\text { Sig. (2-tailed) } \\
\text { N }\end{array}$ & $\begin{array}{r}, 782^{* *} \\
, 000 \\
37\end{array}$ & $\begin{array}{r}, 940^{* *} \\
, 000 \\
37\end{array}$ & \begin{tabular}{r|}
, $953^{* *}$ \\
, 000 \\
37
\end{tabular} & $\begin{array}{r}, 805^{* *} \\
, 000 \\
37\end{array}$ & $\begin{array}{r}, 835^{* *} \\
, 000 \\
37\end{array}$ & . \\
\hline
\end{tabular}

**. Correlation is significant at the 0.01 level (2-tailed). 
Tabel 2. Validitas X2 (Content Sharing)

\begin{tabular}{|c|c|c|c|c|c|c|c|}
\hline & & $\mathrm{X} 2.1$ & $\mathrm{X} 2.2$ & $\mathrm{X} 2.3$ & $\mathrm{X} 2.4$ & $\mathrm{X} 2.5$ & Content Sharing \\
\hline \multirow[t]{3}{*}{$\mathrm{X} 2.1$} & Pearson Correlation & 1 &,- 039 &,$- 450^{* *}$ &, $802^{* *}$ &, $830^{* *}$ &, $819^{* *}$ \\
\hline & Sig. (2-tailed) & & 821 &, 005 &, 000 &, 000 & ,000 \\
\hline & $\mathrm{N}$ & 37 & 37 & 37 & 37 & 37 & 37 \\
\hline \multirow[t]{3}{*}{$\mathrm{X} 2.2$} & Pearson Correlation &,- 039 & 1 &, $629^{* *}$ &,- 080 &,- 155 &, $364^{*}$ \\
\hline & Sig. (2-tailed) &, 821 & &, 000 & ,638 &, 359 &, 027 \\
\hline & $\mathrm{N}$ & 37 & 37 & 37 & 37 & 37 & 37 \\
\hline \multirow[t]{3}{*}{$\mathrm{X} 2.3$} & Pearson Correlation &,$- 450^{* * *}$ & $629^{* * *}$ & 1 &,$- 400^{*}$ &,$- 455^{* *}$ &,- 011 \\
\hline & Sig. (2-tailed) &, 005 &, 000 & &, 014 &, 005 & \\
\hline & $\mathrm{N}$ & 37 & 37 & 37 & 37 & 37 & 37 \\
\hline \multirow[t]{3}{*}{$\mathrm{X} 2.4$} & Pearson Correlation &, $802^{* *}$ &,- 080 &,$- 400^{*}$ & 1 &, $868^{* *}$ &, $834^{* *}$ \\
\hline & Sig. (2-tailed) &, 000 & ,638 &, 014 & &, 000 &, 000 \\
\hline & $\mathrm{N}$ & 37 & 37 & 37 & 37 & 37 & 37 \\
\hline \multirow[t]{3}{*}{$\mathrm{X} 2.5$} & Pearson Correlation &, $830^{* *}$ &,- 155 &,$- 455^{* * *}$ &, $868^{* *}$ & 1 &, $813^{* *}$ \\
\hline & Sig. (2-tailed) &, 000 &, 359 &, 005 &, 000 & &, 000 \\
\hline & $\mathrm{N}$ & 37 & 37 & 37 & 37 & 37 & 37 \\
\hline \multirow{3}{*}{$\begin{array}{l}\text { Content } \\
\text { Sharing }\end{array}$} & Pearson Correlation &, $819^{* *}$ &, $364^{*}$ &,- 011 &, $834^{* *}$ &, $813^{* *}$ & 1 \\
\hline & Sig. (2-tailed) &, 000 & 027 & ,949 &, 000 &, 000 & \\
\hline & $\mathrm{N}$ & 37 & 37 & 37 & 37 & 37 & 37 \\
\hline
\end{tabular}

**. Correlation is significant at the 0.01 level (2-tailed).

*. Correlation is significant at the 0.05 level (2-tailed).

Tabel 3. Uji Validitas X2 (Content Sharing) (Lulus Uji)

\begin{tabular}{|c|c|c|c|c|c|c|}
\hline & & $\mathrm{X} 2.1$ & $\mathrm{X} 2.2$ & $\mathrm{X} 2.4$ & $\mathrm{X} 2.5$ & Content Sharing \\
\hline \multirow[t]{3}{*}{$\mathrm{X} 2.1$} & Pearson Correlation & 1 &,- 039 &, $802^{* *}$ &, $830^{* *}$ &, $819^{* *}$ \\
\hline & Sig. (2-tailed) & &, 821 &, 000 &, 000 & , 000 \\
\hline & $\mathrm{N}$ & 37 & 37 & 37 & 37 & 37 \\
\hline \multirow[t]{3}{*}{$\mathrm{X} 2.2$} & Pearson Correlation &,- 039 & 1 &,- 080 &,- 155 &, $364^{*}$ \\
\hline & Sig. (2-tailed) &, 821 & & ,638 & ,359 & 027 \\
\hline & $\mathrm{N}$ & 37 & 37 & 37 & 37 & 37 \\
\hline \multirow[t]{3}{*}{$\mathrm{X} 2.4$} & Pearson Correlation &, $802^{* *}$ &,- 080 & 1 &, $868^{* *}$ &, $834^{* *}$ \\
\hline & Sig. (2-tailed) &, 000 & ,638 & &, 000 &, 000 \\
\hline & $\mathrm{N}$ & 37 & 37 & 37 & 37 & 37 \\
\hline \multirow[t]{4}{*}{$\mathrm{X} 2.5$} & Pearson Correlation &, $830^{* * *}$ &,- 155 &, $868^{* *}$ & 1 &, $813^{* *}$ \\
\hline & Sig. (2-tailed) &, 000 & ,359 &, 000 & & ,000 \\
\hline & $\mathrm{N}$ & 37 & 37 & 37 & 37 & 37 \\
\hline & Pearson Correlation &, $819^{* *}$ & ,364* &, $834^{* *}$ &, $813^{* *}$ & 1 \\
\hline
\end{tabular}


Pengaruh Social Media Marketing Terhadap Keputusan Pembelian Konsumen...

\begin{tabular}{|ll|r|r|r|r|r|} 
Content & Sig. (2-tailed) &, 000 &, 027 &, 000 &, 000 & 37 \\
Sharing & $\mathrm{N}$ & 37 & 37 & 37 & 37 & 37 \\
\hline
\end{tabular}

**. Correlation is significant at the 0.01 level (2-tailed).

*. Correlation is significant at the 0.05 level (2-tailed).

Tabel 4. Validitas X3 (Connecting)

\begin{tabular}{|c|c|c|c|c|c|}
\hline & & X3.1 & X3.2 & X3.3 & Connecting \\
\hline \multirow[t]{3}{*}{ X3.1 } & Pearson Correlation & 1 &, $642^{* * *}$ &, $584^{* *}$ &, $897^{* *}$ \\
\hline & Sig. (2-tailed) & &, 000 &, 000 & 000 \\
\hline & $\mathrm{N}$ & 37 & 37 & 37 & 37 \\
\hline \multirow[t]{3}{*}{$\mathrm{X} 3.2$} & Pearson Correlation &, $642^{* *}$ & 1 &, $569^{* *}$ &, $821^{* *}$ \\
\hline & Sig. (2-tailed) &, 000 & &, 000 &, 000 \\
\hline & $\mathrm{N}$ & 37 & 37 & 37 & 37 \\
\hline \multirow[t]{3}{*}{ X3.3 } & Pearson Correlation &, $584^{* *}$ &, $569^{* *}$ & 1 &, $841^{* *}$ \\
\hline & Sig. (2-tailed) &, 000 &, 000 & &, 000 \\
\hline & $\mathrm{N}$ & 37 & 37 & 37 & 37 \\
\hline \multirow[t]{3}{*}{ Connecting } & Pearson Correlation &, $897^{* *}$ &, $821^{* *}$ &, $841^{* *}$ & 1 \\
\hline & Sig. (2-tailed) &, 000 &, 000 &, 000 & \\
\hline & $\mathrm{N}$ & 37 & 37 & 37 & 37 \\
\hline
\end{tabular}

**. Correlation is significant at the 0.01 level (2-tailed).

Tabel 5. Validitas X4 (Community Building)

\begin{tabular}{|c|c|c|c|c|c|}
\hline & & $\mathrm{X} 4.1$ & $\mathrm{X} 4.2$ & $\mathrm{X} 4.3$ & $\begin{array}{c}\text { Community } \\
\text { Building } \\
\end{array}$ \\
\hline $\mathrm{X} 4.1$ & $\begin{array}{l}\text { Pearson Correlation } \\
\text { Sig. (2-tailed) } \\
\mathrm{N}\end{array}$ & $\begin{array}{r}1 \\
37 \\
\end{array}$ & $\begin{array}{r}, 883^{* *} \\
, 000 \\
37 \\
\end{array}$ & $\begin{array}{r}, 912^{* * *} \\
, 000 \\
37 \\
\end{array}$ & $\begin{array}{r}, 972^{* *} \\
, 000 \\
37 \\
\end{array}$ \\
\hline $\mathrm{X} 4.2$ & $\begin{array}{l}\text { Pearson Correlation } \\
\text { Sig. (2-tailed) } \\
\mathrm{N}\end{array}$ & $\begin{array}{r}, 883^{* * *} \\
, 000 \\
37 \\
\end{array}$ & $\begin{array}{r}1 \\
37 \\
\end{array}$ & $\begin{array}{r}, 870^{* *} \\
, 000 \\
37 \\
\end{array}$ & $\begin{array}{r}, 950^{* *} \\
, 000 \\
37 \\
\end{array}$ \\
\hline $\mathrm{X} 4.3$ & $\begin{array}{l}\text { Pearson Correlation } \\
\text { Sig. (2-tailed) } \\
\mathrm{N}\end{array}$ & $\begin{array}{r}, 912^{* * *} \\
, 000 \\
37 \\
\end{array}$ & $\begin{array}{r}, 870^{* *} \\
, 000 \\
37 \\
\end{array}$ & $\begin{array}{r}1 \\
37 \\
\end{array}$ & $\begin{array}{r}, 963^{* *} \\
, 000 \\
37 \\
\end{array}$ \\
\hline Community Building & $\begin{array}{l}\text { Pearson Correlation } \\
\text { Sig. (2-tailed) } \\
\mathrm{N}\end{array}$ & $\begin{array}{r}, 972^{* *} \\
, 000 \\
37\end{array}$ & $\begin{array}{r}, 950^{* *} \\
, 000 \\
37\end{array}$ & $\begin{array}{r}, 963^{\text {** }} \\
, 000 \\
37\end{array}$ & $\begin{array}{r}1 \\
37 \\
\end{array}$ \\
\hline
\end{tabular}

**. Correlation is significant at the 0.01 level (2-tailed). 


\section{Uji Reabilitas}

Syarat lulus uji reabilitas data adalah nilai Cronbach Alpha wajib di atas 0,60. Dari hasil uji reabilitas instrument penelitian, seluruhnya memiliki nilai Cronbach Alpha di atas 0,60, yang artinya item pernyataan yang digunakan dalam kuesioner telah lulus uji reabilitas data.

\section{Uji Reabilitas X1}

\begin{tabular}{|r|c|}
\hline $\begin{array}{c}\text { Cronbach's } \\
\text { Alpha }\end{array}$ & $\begin{array}{c}\text { N of } \\
\text { Items }\end{array}$ \\
\hline, 915 & 5 \\
\hline
\end{tabular}

Uji Reabilitas X3

\begin{tabular}{|r|r|}
\hline $\begin{array}{c}\text { Cronbach's } \\
\text { Alpha }\end{array}$ & $\begin{array}{c}\text { N of } \\
\text { Items }\end{array}$ \\
\hline, 794 & 3 \\
\hline
\end{tabular}

Uji Reabilitas X2

\begin{tabular}{|r|r|}
\hline $\begin{array}{c}\text { Cronbach's } \\
\text { Alpha }\end{array}$ & $\begin{array}{c}\text { N of } \\
\text { Items }\end{array}$ \\
\hline, 915 & 5 \\
\hline
\end{tabular}

Uji Reabilitas X4

\begin{tabular}{|r|r|}
\hline $\begin{array}{c}\text { Cronbach's } \\
\text { Alpha }\end{array}$ & $\begin{array}{c}\text { N of } \\
\text { Items }\end{array}$ \\
\hline, 794 & 3 \\
\hline
\end{tabular}

Berdasarkan hasil uji di atas, seluruh item pertanyaan dalam kuesioner dinyatakan valid dan reliabel. Peneliti kemudian menyebarkan kuesioner tersebut kepada sampel yang ditetapkan, dan berhasil memperoleh 200 responden. Di samping itu, peneliti juga melakukan mengobservasi lapangan, kemudian secara sengaja memilih informan kunci yang dianggap memenuhi kriteria penelitian (criterion based-purposive sampling) untuk proses wawancara selanjutnya.

Sumber data primer diperoleh secara langsung melalui penyebaran kuesioner, observasi dan wawancara. Data sekunder diperoleh dari pihak lain atau secara tidak langsung melalui studi pustaka yang relevan. Sebagian besar data yang diperlukan adalah data kuantitatif dengan dukungan dari data kualitatif. Data-data yang diperoleh berupa hasil penyebaran kuesioner, sejarah Kota Denpasar, struktur administrasi dan sosial masyarakat, hasil observasi berupa foto dan video, hasil wawancara dengan informan kunci.

Setelah semua tahapan pengumpulan data berhasil dilaksanakan, pertamatama dilakukan analisis data hasil penyebaran kuesioner menggunakan analisis 
regresi logistik (logistic regression). Melalui proses triangulasi, data yang dikumpulkan diuji kredibilitasnya, divalidasi melalui berbagai teknis dan sumber data, dengan mengikuti langkah-langkah berikut: tabulasi data (hasil kuesioner), reduksi data (data-data yang tidak penting dibuang), penentuan kategori/kelompok data, pemasukan data sesuai kelompoknya, interpretasi data per kelompok, dan interpretasi data seluruhnya (Dantes, 2012: 144). Terakhir, analisis deskriptif dipakai untuk menjelaskan makna-makna yang terkandung di dalamnya.

\section{Hasil dan Pembahasan}

Penelitian ini berhasil memperoleh 200 responden yang pernah menggunakan media sosial sebagai preferensi ketika berkunjung ke berbagai destinasi wisata kuliner di Kota Denpasar. Responden penelitian ini sebagian besar didominasi oleh perempuan (64\%) dan sisanya merupakan laki-laki (36\%). Rentang usia responden dari rentang usia 17 tahun hingga di atas 50 tahun. Sebagian besar berumur orang (40,5\%) dan umur 21 tahun sebanyak 17 orang (8,5\%). Pada latar belakang pendidikan, sebanyak 143 orang (71,5\%) mengenyam pendidikan di jenjang SMA/SMK, sebanyak 51 orang (25,5\%) berpendidikan pada jenjang diploma/S1, dan sebanyak 6 orang (3\%) pada jenjang S2 dan S3. Dominasi generasi millennial cukup beralasan, mengingat mereka merupakan pangsa pasar terbesar dan paling ideal bagi kegiatan social media marketing. Sebagian besar responden saat ini berdomisili di Bali, yakni di Kota Denpasar dan beberapa kabupaten lainnya. Sisanya berdomisili di berbagai daerah di Indonesia, seperti Sumatra, Jawa, Nusa Tenggara Barat, Nusa Tengara Timur, Sulawesi dan Kalimantan. Dengan demikian, social media marketing memiliki jangkauan pasar yang lebih luas dibandingkan dengan pemasaran konvensional yang dibatasi oleh berbagai kondisi geografis.

Penelitian ini menggunakan analisis statistik data berupa analisis regresi logistik, sebagai regresi untuk melihat pengaruh sekaligus menguji probabilitas antara variabel dependen oleh variabel independen 


\section{Uji Validitas 'Content Creation'}

Tabel 6. Correlations

\begin{tabular}{|c|c|c|c|c|c|c|c|}
\hline & & $\mathrm{CC} 1$ & $\mathrm{CC} 2$ & $\mathrm{CC} 3$ & $\mathrm{CC} 4$ & $\mathrm{CC} 5$ & Content Creation \\
\hline \multirow[t]{3}{*}{$\mathrm{CC} 1$} & Pearson Correlation & 1 & $.690^{* *}$ & $.705^{* *}$ & $.718^{* *}$ & $.573^{* *}$ & $.849^{* *}$ \\
\hline & Sig. (2-tailed) & & .000 & .000 & .000 & .000 & .000 \\
\hline & $\mathrm{N}$ & 192 & 192 & 192 & 192 & 192 & 192 \\
\hline \multirow[t]{3}{*}{$\mathrm{CC} 2$} & Pearson Correlation & $.690^{* * *}$ & 1 & $.822^{* * *}$ & $.702^{* *}$ & $.732^{* * *}$ & $.902^{* *}$ \\
\hline & Sig. (2-tailed) & .000 & & .000 & .000 & .000 & .000 \\
\hline & $\mathrm{N}$ & 192 & 192 & 192 & 192 & 192 & 192 \\
\hline \multirow[t]{3}{*}{$\mathrm{CC} 3$} & Pearson Correlation & $.705^{* * *}$ & $.822^{* *}$ & 1 & $.739^{* *}$ & $.742^{* *}$ & $.918^{* *}$ \\
\hline & Sig. (2-tailed) & .000 & .000 & & .000 & .000 & .000 \\
\hline & $\mathrm{N}$ & 192 & 192 & 192 & 192 & 192 & 192 \\
\hline \multirow[t]{3}{*}{$\mathrm{CC} 4$} & Pearson Correlation & $.718^{* * *}$ & $.702^{* *}$ & $.739^{* *}$ & 1 & $.636^{* *}$ & $.871^{* *}$ \\
\hline & Sig. (2-tailed) & .000 & .000 & .000 & & .000 & .000 \\
\hline & $\mathrm{N}$ & 192 & 192 & 192 & 192 & 192 & 192 \\
\hline \multirow[t]{3}{*}{ CC5 } & Pearson Correlation & $.573^{* *}$ & $.732^{* *}$ & $.742^{* *}$ & $.636^{* *}$ & 1 & $.831^{\text {** }}$ \\
\hline & Sig. (2-tailed) & .000 & .000 & .000 & .000 & & .000 \\
\hline & $\mathrm{N}$ & 192 & 192 & 192 & 192 & 192 & 192 \\
\hline Content & Pearson Correlation & $.849^{* *}$ & $.902^{* *}$ & $.918^{* *}$ & $.871^{* *}$ & $.831^{* *}$ & 1 \\
\hline \multirow[t]{2}{*}{ Creation } & Sig. (2-tailed) & .000 & .000 & .000 & .000 & .000 & \\
\hline & $\mathrm{N}$ & 192 & 192 & 192 & 192 & 192 & 192 \\
\hline
\end{tabular}

**. Correlation is significant at the 0.01 level (2-tailed).

Berdasarkan data di atas terlihat bahwa seluruh nilai Sig pada indicator terhadap total tiap indicator adalah kurang dari 0,005 sehingga dikatakan data valid.

\section{Uji Validitas 'Content Sharing'}

Tabel 7. Correlations

\begin{tabular}{llr|r|r|r|r} 
& & \multicolumn{1}{c}{ CS1 } & \multicolumn{1}{c}{ CS2 } & \multicolumn{1}{c}{ CS4 } & CS5 & Content Sharing \\
\hline CS1 & Pearson Correlation & 1 & $.292^{* *}$ & $.756^{* *}$ & $.751^{* *}$ & $.853^{* *}$ \\
\cline { 2 - 7 } & Sig. (2-tailed) & & .000 & .000 & .000 & .000 \\
\hline N & 192 & 192 & 192 & 192 & 192 \\
\hline CS2 & Pearson Correlation & $.292^{* *}$ & 1 & $.444^{* *}$ & $.281^{* *}$ & $.628^{* *}$ \\
\hline & Sig. (2-tailed) & .000 & & .000 & .000 & .000 \\
\hline CS4 & Pearson Correlation & $.756^{* *}$ & $.444^{* *}$ & 1 & $.791^{* *}$ & 192 \\
\hline
\end{tabular}


Pengaruh Social Media Marketing Terhadap Keputusan Pembelian Konsumen...

\begin{tabular}{llr|r|r|r|r}
\hline & $\mathrm{N}$ & 192 & 192 & 192 & 192 & 192 \\
\hline \multirow{2}{*}{ CS5 } & Pearson Correlation & $.751^{* *}$ & $.281^{* *}$ & $.791^{* *}$ & 1 & $.865^{* *}$ \\
\cline { 2 - 7 } & Sig. (2-tailed) & .000 & .000 & .000 & & .000 \\
\cline { 2 - 7 } Content Sharing & $\mathrm{N}$ & 192 & 192 & 192 & 192 & 192 \\
\hline & Pearson Correlation & $.853^{* *}$ & $.628^{* *}$ & $.913^{* *}$ & $.865^{* *}$ & 1 \\
\hline & Sig. (2-tailed) & .000 & .000 & .000 & .000 & 192 \\
\hline
\end{tabular}

**. Correlation is significant at the 0.01 level (2-tailed).

Berdasarkan data di atas terlihat bahwa seluruh nilai Sig pada indicator terhadap total tiap indikator adalah kurang dari 0,005 sehingga dikatakan data valid.

\section{Uji Validitas ‘Connecting'}

Tabel 8. Correlations

\begin{tabular}{|c|c|c|c|c|c|}
\hline & & $\mathrm{CO} 1$ & $\mathrm{CO} 2$ & $\mathrm{CO} 3$ & Connecting \\
\hline \multirow[t]{3}{*}{$\mathrm{CO} 1$} & Pearson Correlation & 1 & $.575^{* *}$ & $.631^{* *}$ & $.852^{* *}$ \\
\hline & Sig. (2-tailed) & & .000 & .000 & .000 \\
\hline & $\mathrm{N}$ & 192 & 192 & 192 & 192 \\
\hline \multirow[t]{3}{*}{$\mathrm{CO} 2$} & Pearson Correlation & $.575^{* *}$ & 1 & $.582^{* *}$ & $.849^{* *}$ \\
\hline & Sig. (2-tailed) & .000 & & .000 & .000 \\
\hline & $\mathrm{N}$ & 192 & 192 & 192 & 192 \\
\hline \multirow[t]{3}{*}{$\mathrm{CO} 3$} & Pearson Correlation & $.631^{* *}$ & $.582^{* *}$ & 1 & $.862^{* *}$ \\
\hline & Sig. (2-tailed) & .000 & .000 & & .000 \\
\hline & $\mathrm{N}$ & 192 & 192 & 192 & 192 \\
\hline \multirow[t]{3}{*}{ Connecting } & Pearson Correlation & $.852^{* *}$ & $.849^{* *}$ & $.862^{* *}$ & 1 \\
\hline & Sig. (2-tailed) & .000 & .000 & .000 & \\
\hline & $\mathrm{N}$ & 192 & 192 & 192 & 192 \\
\hline
\end{tabular}

**. Correlation is significant at the 0.01 level (2-tailed).

Berdasarkan data di atas terlihat bahwa seluruh nilai Sig pada indicator terhadap total tiap indikator adalah kurang dari 0,005 sehingga dikatakan data valid. 


\section{Uji Validitas ‘Community Building'}

Tabel 9. Correlations

\begin{tabular}{|c|c|c|c|c|c|}
\hline & & $\mathrm{CB} 1$ & $\mathrm{CB} 2$ & CB3 & $\begin{array}{c}\text { Community } \\
\text { Building } \\
\end{array}$ \\
\hline \multirow[t]{3}{*}{ CB1 } & Pearson Correlation & 1 & $.705^{* *}$ & $.798^{* *}$ & $.917^{* *}$ \\
\hline & Sig. (2-tailed) & & .000 & .000 & .000 \\
\hline & $\mathrm{N}$ & 192 & 192 & 192 & 192 \\
\hline \multirow[t]{3}{*}{ CB2 } & Pearson Correlation & $.705^{* * *}$ & 1 & $.749^{* *}$ & $.892^{* * *}$ \\
\hline & Sig. (2-tailed) & .000 & & .000 & .000 \\
\hline & $\mathrm{N}$ & 192 & 192 & 192 & 192 \\
\hline \multirow[t]{3}{*}{ CB3 } & Pearson Correlation & $.798^{* *}$ & $.749^{* *}$ & 1 & $.929^{* *}$ \\
\hline & Sig. (2-tailed) & .000 & .000 & & .000 \\
\hline & $\mathrm{N}$ & 192 & 192 & 192 & 192 \\
\hline \multirow[t]{3}{*}{ Community Building } & Pearson Correlation & $.917^{* *}$ & $.892^{* *}$ & $.929^{* *}$ & 1 \\
\hline & Sig. (2-tailed) & .000 & .000 & .000 & \\
\hline & $\mathrm{N}$ & 192 & 192 & 192 & 192 \\
\hline
\end{tabular}

**. Correlation is significant at the 0.01 level (2-tailed).

Berdasarkan data di atas terlihat bahwa seluruh nilai Sig pada indicator terhadap total tiap indikator adalah kurang dari 0,005 sehingga dikatakan data valid.

\section{Uji Reliabilitas}

Tabel 10. Reliabilitas

\begin{tabular}{|c|c|c|c|}
\hline Variabel & \multicolumn{2}{|c|}{ Reliabilitas } & Keterangan \\
\hline \multirow[t]{4}{*}{ Content Creation } & \multirow{2}{*}{\multicolumn{2}{|c|}{ Reliability Statistics }} & \multirow{15}{*}{$\begin{array}{l}\text { Berdasarkan data di samping terlihat } \\
\text { bahwa nilai Cronbach's Alpha dari } \\
\text { seluruh variable adalah LEBIH dari } 0,6 \\
\text { yang berarti seluruh data kuesioner dari } \\
\text { tiap variable adalah reliabel. }\end{array}$} \\
\hline & & & \\
\hline & Cronbach's Alpha & $\mathrm{N}$ of Items & \\
\hline & .922 & 5 & \\
\hline \multirow[t]{4}{*}{ Content Sharing } & \multirow{2}{*}{\multicolumn{2}{|c|}{ Reliability Statistics }} & \\
\hline & & & \\
\hline & Cronbach's Alpha & $\mathrm{N}$ of Items & \\
\hline & .827 & 4 & \\
\hline \multirow[t]{3}{*}{ Connecting } & \multicolumn{2}{|c|}{ Reliability Statistics } & \\
\hline & Cronbach's Alpha & $\mathrm{N}$ of Items & \\
\hline & .814 & 3 & \\
\hline \multirow[t]{4}{*}{ Community Building } & \multirow{2}{*}{\multicolumn{2}{|c|}{ Reliability Statistics }} & \\
\hline & & & \\
\hline & Cronbach's Alpha & $\mathrm{N}$ of Items & \\
\hline & .900 & 3 & \\
\hline
\end{tabular}




\section{Uji Omnibus Test of Model Coefficients}

Tabel 11. Omnibus Tests of Model Coefficients

\begin{tabular}{llr|r|r} 
& & \multicolumn{1}{c|}{ Chi-square } & df & \multicolumn{1}{c}{ Sig. } \\
\hline \multirow{2}{*}{ Step 1 } & Step & 15.487 & 4 & .004 \\
\cline { 2 - 5 } & Block & 15.487 & 4 & .004 \\
\cline { 2 - 5 } & Model & 15.487 & 4 & .004 \\
\hline
\end{tabular}

Uji ini digunakan untuk mengetahui apakah variabel independen secara simultan mempengaruhi variabel dependen. Berdasarkan data di atas terlihat nilai Sig adalah kurang dari 0,05 sehingga dapat dikatakan bahwa terdapat pengaruh yang signifikan dari $\mathrm{x}$ variabel independen secara simultan mempengaruhi variabel dependen.

\section{Uji Hosmer dan Lemeshow (Uji F)}

Hosmer and Lemeshow Test

\begin{tabular}{|c|c|c|c|}
\hline Step & Chi-square & df & Sig. \\
\hline 1 & 13.624 & 8 & .092 \\
\hline
\end{tabular}

Untuk menguji kelayakan model regresi, digunakan uji Hosmer dan Lemeshow dengan pengukuran pada nilai chi square. Berdasarkan data di atas terlihat bahwa nilai Sig adalah lebih dari 0,05 sehingga dapat dikatakan bahwa model regresi dapat diterima.

\section{Uji Nagelkerke R Square}

\begin{tabular}{lr|r|rr} 
& \multicolumn{3}{c}{ Model Summary } \\
Step & $\begin{array}{c}\text {-2 Log } \\
\text { likelihood }\end{array}$ & $\begin{array}{c}\text { Cox \& Snell } \\
\text { R Square }\end{array}$ & \multicolumn{2}{c}{$\begin{array}{c}\text { Nagelkerke R } \\
\text { Square }\end{array}$} \\
\hline 1 & $51.024^{\mathrm{a}}$ & .077 & .265 \\
\hline
\end{tabular}

a. Estimation terminated at iteration number 7 because parameter estimates changed by less than .001 . 
Untuk melihat koefisien determinasi pada regresi logistic, digunakan uji Nagelkerke R Square. Berdasarkan data di atas terlihat nilai Nagelkerke R Square adalah 0,265 yang berarti bahwa variable dependen dapat dijelaskan oleh variable independent sebesar $26,5 \%$. Sisanya berasal dari variable lain yang tidak terdapat dalam model.

Uji Wald atau Uji Parsial $t$

Tabel 12. Variables in the Equation

\begin{tabular}{|c|c|c|c|c|c|c|c|}
\hline & & $\mathrm{B}$ & S.E. & Wald & df & Sig. & $\operatorname{Exp}(B)$ \\
\hline \multirow[t]{5}{*}{ Step $1^{\mathrm{a}}$} & Content Creation & -.227 & .204 & 1.241 & 1 & .265 & .797 \\
\hline & Content Sharing & 1.064 & .347 & 9.393 & 1 & .002 & 2.898 \\
\hline & Connecting & -.534 & .296 & 3.261 & 1 & .071 & .586 \\
\hline & $\begin{array}{l}\text { Community } \\
\text { Building }\end{array}$ & -.542 & .298 & 3.312 & 1 & .069 & .582 \\
\hline & Constant & 4.617 & 2.296 & 4.045 & 1 & .044 & 101.204 \\
\hline
\end{tabular}

a. Variable(s) entered on step 1: Content Creation, Content Sharing, Connecting, Community Building.

Uji Wald digunakan untuk menunjukkan seberapa besar pengaruh variabel independen terhadap variabel independen secara parsial. Berdasarkan data di atas terlihat bahwa

1. Nilai Sig pada Content Sharing adalah kurang dari 0,05 yang berarti bahwa variabel tersebut berpengaruh terhadap Keputusan Pembelian

2. Nilai Sig pada Content Creation, Connecting, Community Building adalah lebih dari 0,05 yang berarti bahwa variabel tersebut tidak berpengaruh terhadap keputusan pembelian

Berdasarkan pada hasil analisis data, variabel independen Content Creation, Content Sharing, Connecting dan Community Building memiliki pengaruh secara simultan dan signifikan terhadap variabel dependen keputusan pembelian pada destinasi wisata kuliner Kota Denpasar sebesar 26,5\%. Secara parsial, signifikasi dari 
variabel Content Creation, Connecting, Community Building tidak berpengaruh terhadap keputusan pembelian. Sebaliknya variabel Content Sharing justru berpengaruh terhadap keputusan pembelian. Berbagai variabel lain yang berpotensi untuk mempengaruhi keputusan pembelian di antaranya faktor-faktor internal dan eksternal, seperti umur, motivasi, persepsi, pengalaman sebelumnya, gaya hidup, status sosial, gender, kondisi ekonomis, fungsionalitas, bauran pemasaran, budaya dan lingkungan.

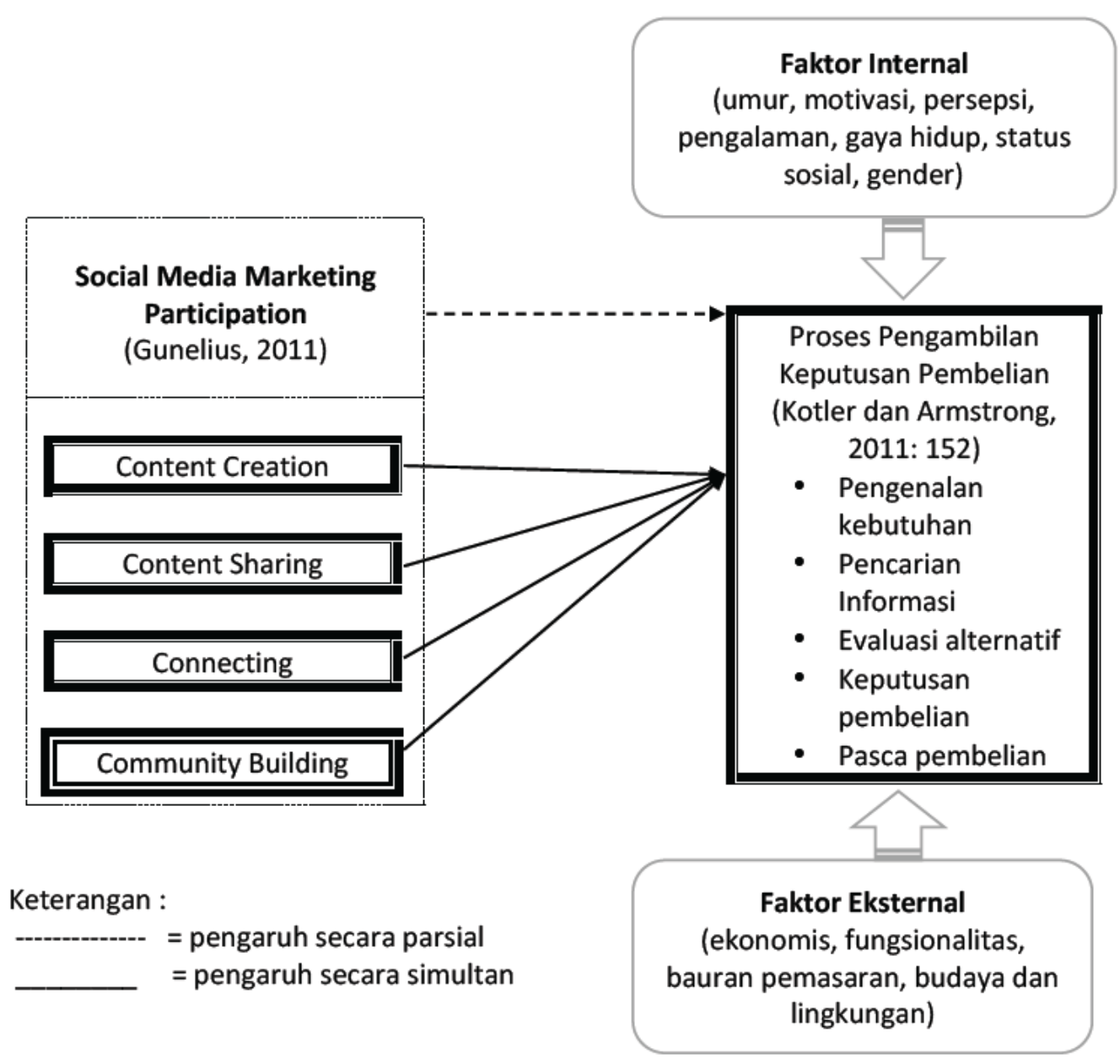

Gambar 2. Model Pengaruh Social Media Marketing terhadap Keputusan Pembelian

Dari 200 orang responden, rentang usia mereka cukup variatif, yakni dari rentang usia 17 tahun hingga di atas 50 tahun. Sebagian besar responden didominasi generasi millennial, yakni umur 18 tahun sebanyak 17 orang $(8,5 \%)$, umur 19 tahun sebanyak 23 orang (11,5\%), umur 20 tahun sebanyak 101 orang (40,5\%) dan umur 21 
tahun sebanyak 17 orang (8,5\%). Pada latar belakang pendidikan, sebanyak 143 orang (71,5\%) mengenyam pendidikan di jenjang SMA/SMK, sebanyak 51 orang $(25,5 \%)$ berpendidikan pada jenjang diploma/S1, dan sebanyak 6 orang (3\%) pada jenjang S2 dan S3. Dominasi generasi millennial cukup beralasan, mengingat mereka merupakan pangsa pasar terbesar dan paling ideal bagi kegiatan social media marketing. Sebagian besar responden saat ini berdomisili di Bali, yakni di Kota Denpasar dan beberapa kabupaten lainnya. Sisanya berdomisili di berbagai daerah di Indonesia, seperti Sumatra, Jawa, Nusa Tenggara Barat, Nusa Tengara Timur, Sulawesi dan Kalimantan.

Berselancar di media sosial sudah merupakan sebuah gaya hidup bagi mayoritas masyarakat kita, dan lebih banyak waktu dihabiskan di sosial media dibandingkan dengan mengakses media lainnya. Dengan demikian, social media marketing memiliki potensi yang lebih besar dan jangkauan pasar yang lebih luas dibandingkan dengan pemasaran konvensional yang dibatasi oleh berbagai kondisi geografis dan saat ini sudah mulai ditinggalkan.

Dwi A. (36), merupakan pemilik restoran street food Baliku Jamur yang sangat populer di kalangan anak-anak muda Kota Denpasar. Kesuksesannya di bidang usaha kuliner tidak datang dengan sendirinya. Sejak 2011, ia membudidayakan jamur tiram di rumahnya sendiri, kemudian tahun 2012 mulai berjualan jamur goreng memakai gerobak sederhana. Tahun 2014 - 2016 Baliku jamur telah membuka 30 cabang kemitraan di beberapa kabupaten di bali. Pada tahun 2017, ia memberanikan diri membuka Baliku Jamur versi restoran di kawasan kuliner Hayam Wuruk yang sangat ramai pengunjung. Saat ini restoran Baliku Jamur berhasil membuka cabang ke 2 di kawasan wisata kuliner Teuku Umar Barat, Denpasar. Terkait dengan content sharing, ia menjelaskan sebagai berikut :

"Untuk pemasaran, kami (Baliku Jamur) menggunakan akun sosial media yg ada Facbook, Instagram dan Tiktok. Kami mulai dengan membuat konten-konten yang relevan, sharing ke followers, termasuk bekerjasama endorsment dan iklan 
berbayar. Pemasaran kami paling fokus Instagram, selain konten kami bisa di repost, juga karena rentang usia pengguna Instagam paling cocok dengan segmentasi market kami" (Dwi A, wawancara, 24 Juli 2021).

Pernyataan tersebut sesuai dengan hasil analisis data yang diperoleh, bahwa jenis media sosial yang paling sering digunakan untuk mengakses informasi terkait destinasi wisata kuliner di Kota Denpasar adalah Instagram (81\%), diikuti oleh Tiktok $(10,5 \%)$, Facebook (2,5\%), Youtube (2,5\%) dan media sosial lainnya. Dengan demikian, Instagram dan Tiktok merupakan aplikasi media sosial yang paling populer di kalangan anak-anak muda millenial, sekaligus sebagai preferensi utama generasi millennial ketika memilih destinasi wisata kuliner yang akan mereka kunjungi.

Terkait dengan hal di atas, penggunaan media sosial memungkinkan perusahaan dan pelanggan untuk terhubung melalui cara yang tidak mungkin dilakukan di masa lalu. Keterhubungan tersebut diberdayakan oleh berbagai platform sosial, seperti situs jejaring sosial (misalnya, Facebook), situs microblogging (misalnya, Twitter), dan komunitas konten (misalnya, YouTube), yang memungkinkan jaringan sosial untuk membangun dari minat dan nilai bersama (Kaplan dan Haelin 2010).

Motivasi adalah pendorong seseorang untuk bertindak, termasuk motivasi untuk berkunjung ke destinasi wisata kuliner. Berdasarkan hasil analisis data, motivasi utama pengunjung untuk datang ke destinasi wisata kuliner di Kota Denpasar adalah menikmati makanan dan minuman yang tersedia (43,5\%), bersosialisasi atau hang out (27\%), mencoba hal baru $(13,5 \%)$ dan family time $(12,5 \%)$. Selain itu ada pula yang datang sambil bekerja (remote worker) dan tujuan romantisme. Terkait dengan hal tersebut, faktor penting yang paling berpengaruh bagi pengunjung untuk datang adalah kualitas, rasa dan porsi makanan/minuman (29,5\%), seberapa viral atau trending di media sosial (24,5\%), jenis/variasi makanan/minuman 
(19\%), nuansa atau ambience lokasi (10\%), harga (7\%) serta aspek kebersihan, higienisitas dan sanitasi (5,5\%).

Bagi pengusaha, setiap restoran memiliki kualitas, rasa dan porsi makanan/minuman masing-masing, yang sekaligus memberikan karakter pada usaha kuliner mereka. Demikian pula dengan nuansa lingkungan dan kebersihan. Mereka mengakui bahwa usaha mereka sangat terbantu dengan konten yang dibuat khusus untuk social media marketing (content creation). Untuk itu mereka berupaya memaksimalkan jangkauan social media marketing dengan membuat beraneka konten kreatif yang berpotensi viral. Eka S (34), pemilik usaha kuliner Rakii Takoyaki dan Crabytos yang popular di Denpasar menyatakan:

"Terkait menciptakan konten yang viral, kami mempelajari trend dengan banyak melihat sosial media, kemudian memposisikan diri sebagai pengguna sosial media itu sendiri. Kami belajar dari akun sosial media lain yang sudah berhasil menciptakan konten yang sukses menarik perhatian" (Eka S, wawancara, 28 Juli 2021).

Hubungan yang baik dengan pelanggan potensial sebaiknya sudah dimulai dengan membangun interaksi dengan pengunjung pada berbagai bentuk upaya promosi di sosial media (connecting). Menurut Chaffey (2016 dalam Mbwana 2018²) interaksi langsung (one - on - one) pada platform media sosial antara brand (usaha) dan konsumen dapat membangun hubungan jangka panjang yang pada akhirnya menguntungkan bagi bisnis. Hal ini juga disampaikan oleh Ashley dan Tuten (2015) ${ }^{3}$. Terkait dengan hal tersebut, Ratih (30), pemilik usaha restoran Baksobar dan Ayam Geprek Madagaskar yang telah berhasil membuka cabang di beberapa tempat di

\footnotetext{
${ }^{1}$ Chaffey, D. 2016. Global Social Media Research Summary 2016. Smart Insights: Social Media Marketing

${ }^{2}$ Mbwana, Khamis Abdul. 2018. Influence of Social Media Marketing on Performance of Small and Medium Enterprises in Nairobi Vounty, Kenya. Thesis. University of Nairobi

${ }^{3}$ Ashley. C dan Tuten, T. 2015. Creative Strategies in Social Media Marketing: an exploratory study of branded social content and consumer engagement. Psychology \& Marketing 32(1), 15-27
} 
Denpasar dan kabupaten lain di Bali mengakui interaksi dan hubungan dengan konsumen sebagai sesuatu yang penting, menurutnya:

"Agar terhubung dengan konsumen maupun calon konsumen, kami membuat konten yang memicu interaksi seperti kuis, give away, ask me question dan lainnna. Kami selalu membalas komen-komen yang masuk, merepost story pelanggan, mengucapkan terima kasih, pada pesan DM kami chat seperti seorang teman kepada mereka, serta memposisikan diri sebagai admin yang berkarakter ramah dan lucu" (Ratih, wawancara, 29 Juli 2021).

Berdasarkan fakta di atas, media sosial telah mengubah cara perusahaan dan pelanggan berinteraksi dan saling mempengaruhi. Interaksi sosial melibatkan "tindakan", baik melalui komunikasi atau pengamatan pasif, yang pada akhirnya bisa mempengaruhi pilihan dan perilaku konsumsi orang lain (Chen et al. ${ }^{42011) .}$ Pengaruh ini dapat menjadi lebih kuat (powerful) jika social media marketing mampu diterapkan dengan baik oleh para pengusaha bisnis kuliner di Kota Denpasar.

Setiap kali berkunjung ke destinasi wisata kuliner, sebagian besar responden lebih senang datang bersama teman-teman akrab/ grup kecil (52\%), bersama pasangan/orang terdekat (19\%) dan keluarga (18\%). Berdasarkan hasil analisis data, dalam satu kali kunjungan ke destinasi wisata kuliner pengeluaran rata-rata mereka cukup variatif. Paling dominan, 157 orang (77\%) menjawab rata-rata pengeluaran mereka antara Rp.50.000 - Rp. 200.000, dan 23 orang (11, 5\%) antara Rp 200.000 hingga Rp. 500.000 dalam satu kali kunjungan. Jumlah pengeluaran tersebut cukup beralasan mengingat mayoritas pengunjung destinasi wisata kuliner Kota Denpasar adalah anak-anak muda generasi millennial yang belum bekerja, fresh graduate atau baru mulai bekerja.

\footnotetext{
${ }^{4}$ Chen, Y., Wang, Q., \& Xie, J. (2011). Online social interactions: A natural experiment on word of mouth versus observational learning. Journal of Marketing Research, 48(2), 238-254.
} 
Agar bisnis bisa berkelanjutan, pengusaha kuliner juga perlu berupaya membangun semacam komunitas (community) untuk memperoleh data, informasi trend terbaru, sekaligus menjaga pelanggan-pelanggan mereka. Proliferasi data pada media sosial memungkinkan perusahaan untuk mengelola hubungan pelanggan dengan lebih baik dan meningkatkan pengambilan keputusan dalam bisnis (Libai et al. 2010) $)^{5}$. Dengan demikian, perusahaan bisa mengambil kepuusan yang tepat berdasarkan masukan data-data yang dieprolehnya. Di sisi lain, pelanggan merasa dihargai, memiliki rasa bangga dan terkoneksi secara sosial, bahkan bisa merasa seperti sebuah keluarga besar. Dwi Antara mengakui hal ini tidaklah mudah, menurutnya:

"Membangun komunitas masih menjadi PR besar kami, sejauh ini komunitas yang sudah terbentuk berupa kumpulan follower di akun sosmed kami. Mereka rata2 merupakan hot dan warm market. Mereka sudah ter edukasi, bahkan sudah bolak balik membeli. Ke depan diupayakan agar kami bisa memberikan value pada mereka berupa identitas atau jati diri, yaitu user produk kami bisa memiliki persepsi bahwa merka adalah bagian dari komunitas pecinta kuliner jalanan, sesuai dengan tag line kami, "pecinta kuliner jalanan" (Dwi Antara, wawancara, 24 Juli 2021).

Pada posisi pertama, tipe destinasi kuliner yang paling banyak dikunjungi dan menjadi favorit adalah tipe kuliner dengan kearifan lokal, seperti angkringan, lesehan, lalapan, pedagang nasi jinggo dan aneka street food. Posisi kedua tipe destinasi kuliner etnik/khas nusantara, seperti rumah makan Babi Guling, rumah makan Padang, rumah makan Sunda dan lainnya. Pada posisi ketiga, adalah tipe restoran fast food internasional, seperti KFC atau McDonalds. Berbagai tipe destinasi kuliner lainnya yang menjadi favorit di Kota Denpasar meliputi café style, casual dining, restoran

${ }^{5}$ Libai, B., Bolton, R., Bugel, M. S., de Ruyter, K., Gotz, O., Risselada, H., \& Stephen, A. T. (2010). Customer-to-customer interactions: Broadening the scope of word of mouth research. Journal of Service Research, 13(3), 267-282. 
keluarga ramah anak (biasanya dilengkapi dengan arena bermain anak), food booth dan fine dining restaurant.

Berdasarkan hasil observasi, beberapa destinasi wisata kuliner Kota Denpasar dengan tipe kearifan lokal, (dominan lesehan dan angkringan) selalu ramai dan padat pengujung, terutama saat akhir pekan. Selain menyediakan jenis makanan yang beragam, harganya pun ramah di kantong anak-anak muda. Sambil makan mereka bisa mengobrol santai dan menikmati hiburan berupa live music. Sementara segmen pasar yang lebih matang dari segi umur, finansial dan sudah berkeluarga cenderung memilih destinasi wisata kuliner lebih berkualitas dan ramah anak, seperti restoran yang dilengkapi arena bermain atau play ground.

\section{Kesimpulan}

Mengacu pada hasil analisis data, berbagai alat pemasaran yang bisa digunakan untuk memaksimalkan partisipasi dalam social media marketing, seperti : Content Creation, Content Sharing, Connecting dan Community Building memiliki pengaruh secara simultan dan signifikan terhadap variabel keputusan pembelian pengunjung pada destinasi wisata kuliner Kota Denpasar. Meskipun demikian, keputusan pembelian hanya dapat dipengaruhi oleh variabel independen sebesar $26,5 \%$ saja. Sisanya berasal dari variabel lain yang tidak terdapat dalam model. Hal ini cukup beralasan, mengingat secara parsial, signifikasi dari variabel Content Creation, Connecting, Community Building tidak berpengaruh terhadap keputusan pembelian. Sebaliknya variable Content Sharing justru berpengaruh terhadap keputusan pembelian. Berbagai variabel lain yang berpotensi untuk mempengaruhi keputusan pembelian di antaranya faktor-faktor internal dan eksternal. Faktor internal meliputi: umur, motivasi, persepsi, pengalaman sebelumnya, gaya hidup, status sosial, gender. Faktor eksternal meliputi: ekonomis, fungsionalitas, bauran pemasaran, budaya dan lingkungan. Beberapa dampak social media marketing pada bisnis, antara lain: 1. Social media marketing memungkinkan perusahaan dan 
pelanggan untuk terhubung cara yang tidak mungkin dilakukan di masa lalu. 2. Social media marketing telah mengubah cara perusahaan dan pelanggan berinteraksi dan saling mempengaruhi, termasuk kemampuan mempengaruhi pilihan dan perilaku konsumsi orang lain. 3. Pengumpulan informasi social media marketing dan komunitas pelanggan, memungkinkan perusahaan untuk mengelola hubungan bisnis yang lebih baik, dan meningkatkan ketepatan dalam pengambilan keputusan.

\section{Ucapan Terima Kasih}

Penelitian ini dibiayai oleh DIPA PNBP Universitas Udayana TA-2021. Tim Peneliti menyampaikan apresiasi dan terima kasih kepada Kementerian Pendidikan dan Kebudayaan Republik Indonesia, Rektor Universitas Udayana, Ketua Lembaga Penelitian dan Pengabdian Kepada Masyarakat (LPPM) Universitas Udayana, Dekan Fakultas Pariwisata Universitas Udayana, dan Koprodi Sarjana Pariwisata, Fakultas Pariwisata Universitas Udayana yang telah memberikan dukungan moral, sarana, prasarana dan dukungan finansial. Kami juga menyampaikan terima kasih kepada narasumber dan semua pihak yang telah membantu terlaksananya penelitian ini.

\section{Daftar Pustaka}

Ashley. C dan Tuten, T. 2015. 'Creative Strategies in Social Media Merketing : an exploratory study of branded social content and consumer engagement'. dalam Psychology E Marketing 32 (1), 15-27

Caleb T Carr, Rebecca A Hayes. 2015. 'Social Media: Defining, Developing and Divining'. Atlantic Journal of Communication. Volume 23, 2015 - Issue 1

Chaffey, D. 2016. Global Social Media Research Summary 2016. Smart Insights : Social Media Merketing

Chen, Y., Wang, Q., \& Xie, J. (2011). 'Online social interactions: A natural experiment on word of mouth versus observational learning'. Dalam Journal of Marketing Research, 48(2), 238-254.

Cohen, R.B., 2008. The Virtual Worlds and the Transformation of Business. Cohen Communication 
http://www.athenaalliance.org/pdf/VirtualWorldsandtheTransformationofBu siness.pdf

Cuming, L., 2008. Engaging Consumers Online: The Impact of Social Media on Purchasing Behaviour. DEI Worldwide, [online] dalam http://www.deiworldwide.com/files/DEIStudEngaging\%20ConsumersOnline Summary.pdf

Dinas Pariwisata Kota Denpasar. 2019. Data Usaha Jasa Makanan dan Minuman Kota Denpasar Tahun 2019 dalamhttps://pariwisata.denpasarkota.go.id/uploads/download/download_20 1305100543_Jumlahusahamakanandanminumandikota denpasar.pdf

Data Reportal. 2020 https://datareportal.com/reports/digital-2020-july-global-statshot, diakses pada tanggal 25 November 2020

Fauser, S.G. Wiedenhofer, J. dan Lorenz, M., 2011. “Touchpoint social web": an explorative study about using the social web for influencing high involvement purchase decisions'. Dalam Problems and Perspectives in Management, 9(1), hal.39-45.

Golden, M., 2011. Social Media Strategies for Professionals and Their Firms: The Guide to Establishing Credibility and Accelerating Relationships. New Jersey: John Wiley and Sons.

Gunelius, Susan. 2011. 30 Minute Social Media Marketing. United States : McGraw Hill

Hermawan, Agus. 2012. Komunikasi Pemasaran. Jakarta : Erlangga

Kaplan, A. M., dan Haenlein, M. (2010). 'Users of The World, Unite! The Challenges and Opportunities of Social Media'. dalam Business Horizons, 53(1), hal 59-68.

Kompas.com

https://denpasar.kompas.com/read/2010/10/22/16131789/denpasar.kembangka n.wisata.kuliner diakses tanggal 25 November 2020)

Kotler, Philip dan Armstrong, Gary. 2011. Principles of Marketing. 14th Eds. Pearson : USA

Kotler, Philip dan Gary Armstrong. 2008. Prinsip-Prinsip Pemasaran. diterjemahkan oleh : Bob Sabran. Edisi kedua belas. Jilid 2. Jakarta : Erlangga

Kotler, Philip, Kevin Lane Keller. 2012. Marketing Management,14th Edition. United States of America : Pearson

Libai, B., Bolton, R., Bugel,M. S., de Ruyter, K., Gotz, O., Risselada, H., dan Stephen, A. T. (2010). 'Customer-to-customer interactions: Broadening the scope of word of mouth research'. dalam Journal of Service Research, 13(3), 267-282.

Mayfield, T.D., 2008. What is social media? [e-book] iCrossing. Dalam www.icrossing.co.uk/.../What_is_Social_Media_iCrossing_ebook.pdf 
Mbwana, Khamis Abdul. 2018. 'Influence of Social Media Merketing on Performance of Small and Medium Enterprises in Nairobi Vounty, Kenya'. Thesis. University of Nairobi

Mileva, Lubiana dan Fauzi Achmad. 2018. 'Pengaruh Social Media Marketing Terhadap Keputusan Pembelian'. dalam Jurnal Administrasi Bisnis (JAB). Vol 58 No. 1.

Moriansyah, La. 2015. 'Pemasaran Melalui Media Sosial: Antecedents dan Consequences'. Jurnal Penelitian Komunikasi dan Opini Publik Vol. 19 No.3, Desember 2015: 187-196

Solis, Brian. 2010. Engage : The Complete Guide for Brands and Businesses to Build, Cultivate, and Measure Success in the New Web. New Jersey : Wiley

Sumarwan, Ujang. 2014. Perilaku Konsumen: Teori dan Penerapannya dalam Pemasaran. Bogor : Ghalia Indonesia

Tuten, Tracy L. 2008. Advertising 2.0 Social Media Marketing in a Web 2.0 World. Connecticut : Praeger

Umami, Zahrotul. 2015. 'Social Strategy Pada Media Sosial Untuk Promosi Pariwisata Daerah Istimewa Yogyakarta'. Interaksi: Jurnal Ilmu Komunikasi, vol. 4, no. 2, pp. 195-201

Weinberg, Tamar. 2009. The New Community Rules : Marketing on the Social Web. California : O' Reilly

Wilem, A, Tumbel AL dan Samadi, RL. 2020. 'Analisis Efektivitas Marketing Media Sosial Facebook Terhadap Keputusan Pelanggan D’brothers Laundry' dalam Jurnal EMBA Vol.8 No.1 Januari 2020, Hal. 156 - 165

Zimmerman, Dan and Doug Sahlin. 2010. Social Media Marketing All in One for Dummies. New Jersey: Wiley Publishing

\section{Profil Penulis}

Nararya Narottama merupakan seorang dosen tetap di Fakultas Pariwisata, Universitas Udayana. Sebelum terjun ke dunia akademis, ia pernah bekerja di beberapa international chain hotel di Bali, Amerika dan Kanada. Pada tahun 2012 ia menyelesaikan pendidikan S2 di Université Paris 1 Pantheon - Sorbonne, Paris, Perancis, dan tahun 2019 lalu berhasil meraih gelar Doktor pada bidang pariwisata di Universitas Udayana. Selain aktif mengajar, saat ini ia telah menerbitkan beberapa 
buah buku, prosiding dan menulis di jurnal ilmiah pada lingkup wisata spiritual, sosial-budaya, ekpatriasi dan migrasi internasional.

Natasha Erinda Putri Moniaga adalah salah seorang dosen di Fakultas Pariwisata, Universitas Udayana. Baru memasuki dunia akademis selama setahun belakangan dan sejauh ini sedang berjuang menyelesaikan pendidikan S3-nya. Fokus dan ketertarikan dalam penelitian bidang ilmu pariwisata adalah psikologi, semiotika visual, bahasa, dan content marketing. Di waktu luangnya gemar menulis fiksi ilmiah, fotografi, bertualang, serta meracik berbagai jenis teh. 